\title{
A checklist of angiosperm diversity surrounding Awba Dam: an important reservoir in Ibadan, Nigeria
}

\author{
Emmanuel Chukwudi Chukwuma* and Tola Abiodun Adebisi-Fagbohungbe \\ Department of Forest Conservation \& Protection, Forestry Research Institute of Nigeria, PMB 5054, Jericho Hills, Ibadan, Nigeria
}

\section{Article history}

Received: 19 July 2015

Accepted: 4 September 2015

Published online: 1 October 2015

(C) Chukwuma, E. C. and AdebisiFagbohungbe, T. A. (2015)

\section{Publisher}

Horizon e-Publishing Group

Corresponding Author

E. C. Chukwuma

$\square_{\text {chukwuma.ec@frin.gov.ng }}$ chukwumaemma@gmail.com

\begin{abstract}
The present study undertakes an enumeration of the existing flora species around Awba dam, located within the University of Ibadan, Ibadan, Nigeria. Methods followed conventional practice as reported by previous authors of related studies. Findings showed that the study area is very rich in biodiversity. A total of 119 species in 47 families were recorded. The large number of species recorded, especially herbs which contribute $37 \%$ of the total enumeration suggest that the site may be further accessed for medicinal plant species which could possess beneficial health properties. Nonetheless, the presence of fauna and phytoplankton species also indicates their role in ecosystem balancing and thus sustaining human livelihood. With the continuous developmental activities, practical conservation approaches is ideal if the study area is to be saved from total loss of species.
\end{abstract}

Keywords

Awba dam; flora; biodiversity; conservation

Chukwuma, E. C. and Adebisi-Fagbohungbe, T. A. 2015. A checklist of angiosperm diversity surrounding Awba Dam: an important reservoir in Ibadan, Nigeria. Plant Science Today 2(4): 116122. http://dx.doi.org/10.14719/pst.2015.2.4.135

\section{Introduction}

Assessment of biological diversity in a particular area has continued to be of interest to scientists around the world. Nigeria, with numerous flora and fauna species, has been faced with challenges to species conservation, gradually leading to total disappearance of these human sustainers (plants and animals). Several authors have documented the existing angiosperm species in some parts of the country (Soladoye et al., 2005; Soladoye et al., 2011; Ariwaodo et al., 2012; Ayodele et al., 2013), and with particular reference to their medicinal values (Gills, 1992; Adesina et al., 1995; Schmidt, 1996; Soladoye \& Oni, 1996; Okoli et al., 2007; Odugbemi, 2008; Soladoye et al., 2012). Gbile et al. (1978) recorded 492 plant species in 112 families to be threatened, and in 1981 they compiled 480 rare plant species. Oguntala et al. (1996) reported 85 endangered tree species for Cross River State and its environs. As put by Valdecasas \& Camacho (2003), the value of any biodiversity analysis and the adequacy of conservation measures depend on the quality of basic data. The data for biodiversity and conservation however, is mainly taxonomic. Much has been discussed about the phytoplankton and water quality of Awba reservoir (Akin-Oriola,
2003; Anago et al., 2013; Okeniyi et al., 2013; Tyokumbur \& Okorie, 2013), but little is known about the rich angiosperm diversity which this important dam accommodates. With the recent threats resulting from the depletion of ozone layer, deforestation activities and rapid rate of urbanization, it has become imperative to constantly conduct biodiversity assessment of our forests and the entire ecosystems. This work thus takes into account, the existing flora species around Awba dam, located within the University of Ibadan, Ibadan, Nigeria. It also highlights the importance of some identified plant species and discourages further habitat destruction by the university community, to checkmate species extinction.

\section{Materials and methods Study area}

Awba dam reservoir is located at the south-western end of the University of Ibadan. It was constructed in 1964 by draining the Awba stream and impounding the water at a point where it flows through a natural valley. It lies on latitude $7^{\circ} 26^{\prime} \mathrm{N}$ and longitude $3^{\circ} 53^{\prime} \mathrm{E}$, and at an altitude of $209 \mathrm{~m}$ above sea level (Fig 1). The 
Table 1. List of identified species around the study area

\begin{tabular}{|c|c|c|c|c|}
\hline S/No & Species & Family & Habit & Local Name \\
\hline 1 & Acalypha ciliata Forssk. & Euphorbiaceae & Herb & Jinwinini \\
\hline 2 & Alchornea cordifolia (Schumach. et Thonn.) Mull. Arg. & Euphorbiaceae & Shrub & Ewe-ifa, ipa \\
\hline 3 & Alchornea laxiflora (Benth.) Pax et K. Hoffm. & Euphorbiaceae & Shrub & Ijan \\
\hline 4 & Bridelia ferruginea Benth. & Euphorbiaceae & Tree & Ira-odan \\
\hline 5 & Croton lobatus L. & Euphorbiaceae & Herb & Eru \\
\hline 6 & Euphorbia graminea J.Koenig ex Boiss. & Euphorbiaceae & Herb & - \\
\hline 7 & Euphorbia heterophylla L. & Euphorbiaceae & Herb & Egele \\
\hline 8 & Euphorbia hirta L. & Euphorbiaceae & Herb & Emile \\
\hline 9 & Hura crepitans $\mathrm{L}$. & Euphorbiaceae & Tree & - \\
\hline 10 & Mallotus oppositifolius (Geiseler) Mull. Arg. & Euphorbiaceae & Herb & Ebewosa \\
\hline 11 & Manihot esculenta Crantz. & Euphorbiaceae & Shrub & Paki \\
\hline 12 & Margaritaria discoidea (Baill.) G.L. Webster & Euphorbiaceae & Tree & - \\
\hline 13 & Phyllanthus amarus Schumach. et Thonn. & Euphorbiaceae & Herb & Eyin-olobe \\
\hline 14 & Ricinus communis L. & Euphorbiaceae & Shrub & Upe-erenla \\
\hline 15 & Securinega virosa (Roxb. ex Willd.) Baill. & Euphorbiaceae & Shrub & - \\
\hline 16 & Ageratum conyzoides L. & Asteraceae & Herb & Imi-esu \\
\hline 17 & Aspilia africana (Pers.) C.D. Adams & Asteraceae & Herb & Yunriyun \\
\hline 18 & Chromolaena odorata (L.) R.M. King et H. Rob. & Asteraceae & Herb & Akintola \\
\hline 19 & Melanthera scandens (Schumach. et Thonn.) Roberty & Asteraceae & Herb & Abo-yunyun \\
\hline 20 & Synedrella nodiflora (L.) Gaertn. & Asteraceae & Herb & Akoyunyun \\
\hline 21 & Tithonia diversifolia A. Gray & Asteraceae & Shrub & Agbale \\
\hline 22 & Vernonia amygdalina Delile & Asteraceae & Shrub & Ewuro \\
\hline 23 & Vernonia cinerea (L.) Less. & Asteraceae & Herb & Bojure \\
\hline 24 & Antians toxicaria var. africana A. Chev. & Moraceae & Tree & Ooro \\
\hline 25 & Ficus exasperata Vahl & Moraceae & Tree & Epin \\
\hline 26 & Ficus lutea Vahl & Moraceae & Tree & Oba-odan \\
\hline 27 & Ficus mucuso Welw. ex Ficalho & Moraceae & Tree & Obobo \\
\hline 28 & Ficus natalensis subsp leprieurii (Miq.) C.C. berd & Moraceae & Tree & Abadan, ogabe \\
\hline 29 & Milicia excelsa (Welw.) C.C. Berg. & Moraceae & Tree & Iroko \\
\hline 30 & Morus mesozygia Stapf. & Moraceae & Tree & Aye \\
\hline 31 & Calopogonium mucunoides Desv. & Papilionaceae & Creeper & Apalofa,Agbiri \\
\hline 32 & Centrosema pubescens Benth. & Papilionaceae & Climber & Ewa-ahun \\
\hline 33 & Desmodium gangeticum (L.) DC. & Papilionaceae & Shrub & Ewe-emo \\
\hline 34 & Desmodium scorpiurus (Sw.) Desv. & Papilionaceae & Climber & - \\
\hline 35 & Gliricidia sepium (Jacq.) Walp. & Papilionaceae & Tree & Agunmaniye \\
\hline 36 & Indigofera spicata Forssk. & Papilionaceae & Creeper & - \\
\hline 37 & Milletia thonningii (Schum. et Thonn.) Baker. & Papilionaceae & Tree & Ito \\
\hline 38 & Alternanthera brasiliana (L.) Kuntze & Amaranthaceae & Herb & - \\
\hline 39 & Alternanthera sessilis ((L.) DC. & Amaranthaceae & Herb & Rekureku \\
\hline 40 & Celosia leptostachya Benth. & Amaranthaceae & Herb & Ajefawo \\
\hline 41 & Cyataula prostata (L.) Blume & Amaranthaceae & Herb & Sewerepepe \\
\hline 42 & Gomphrena celosioides Mart. & Amaranthaceae & Herb & Ipopo ale \\
\hline 43 & Afzelia africana $\mathrm{Sm}$. & Caesalpiniaceae & Tree & Apa \\
\hline 44 & Delonix regia (Hook.) Raf. & Caesalpiniaceae & Tree & Sekkeseke \\
\hline 45 & Senna hirsuta (L.) H.S.Irwin \& Barneby & Caesalpiniaceae & Shrub & Rere \\
\hline 46 & Senna obtusifolia (L.) H.S.Irwin \& Barneby & Caesalpiniaceae & Shrub & Eru asundegbe \\
\hline 47 & Senna siamea (Lam.) H.S.Irwin \& Barneby & Caesalpiniaceae & Tree & - \\
\hline 48 & Hibiscus asper Hook.f. & Malvaceae & Shrub & Isapa \\
\hline 49 & Malvastrum coromandelianum (L.) Garcke & Malvaceae & Herb & - \\
\hline 50 & Sida corymbosa R. E. Fr. & Malvaceae & Herb & Isekotu \\
\hline 51 & Sida veronicifolia Lam. & Malvaceae & Creeper & - \\
\hline 52 & Urena lobata L. & Malvaceae & Shrub & Efore-loka \\
\hline 53 & Borreria ocymoides (Burm. f.) DC. & Rubiaceae & Herb & - \\
\hline 54 & Chassalia kolly (Schumach.) Hepper & Rubiaceae & Herb & Tutugbo \\
\hline 55 & Diodia scandens Sw. & Rubiaceae & Herb & - \\
\hline 56 & Morinda lucida L. & Rubiaceae & Tree & Oruwo \\
\hline 57 & Oldenlandia corimbosa $\mathrm{L}$. & Rubiaceae & Herb & Oyigi \\
\hline 58 & Albizia lebbeck (L.) Benth. & Mimosaceae & Tree & Igbagbo \\
\hline 59 & Albizia zygia (DC.) J.F. Macbr. & Mimosaceae & Tree & Ayunre \\
\hline 60 & Leucaena leucocephala (Lam.) de Wit & Mimosaceae & Tree & \\
\hline 61 & Mimosa invisa Mart. & Mimosaceae & Herb & - \\
\hline 62 & Andropogon sp. & Poaceae & Shrub & - \\
\hline 63 & Bambusa vulgaris Schrad. ex Wendel & Poaceae & Shrub & Oparun \\
\hline 64 & Saccharum officinarum L. & Poaceae & Shrub & Ireke \\
\hline 65 & Tridax procumbens $\mathrm{L}$. & Poaceae & Herb & Igbalode \\
\hline 66 & Allophylus africanus P. Beauv. f. & Sapindaceae & Tree & Eekan-ehoro \\
\hline 67 & Bligha unijigata Baker & Sapindaceae & Tree & Isin-oko \\
\hline 68 & Blighia sapida K.D. Koenig & Sapindaceae & Tree & Isin \\
\hline 69 & Paullinia pinnata $\mathrm{L}$. & Sapindaceae & Climber & Itakun-okere \\
\hline 70 & Ipomoea asarifolia (Desr. et Schult.) Roem. et Schult. & Convolvulaceae & Herb & Ewe-gboro \\
\hline 71 & Ipomoea involucrata P. Beauv. & Convolvulaceae & Climber & Alukerese \\
\hline 72 & Merremia kentrocaulos Rendle & Convolvulaceae & Creeper & \\
\hline
\end{tabular}


Table 1. List of identified species around the study area Contd..

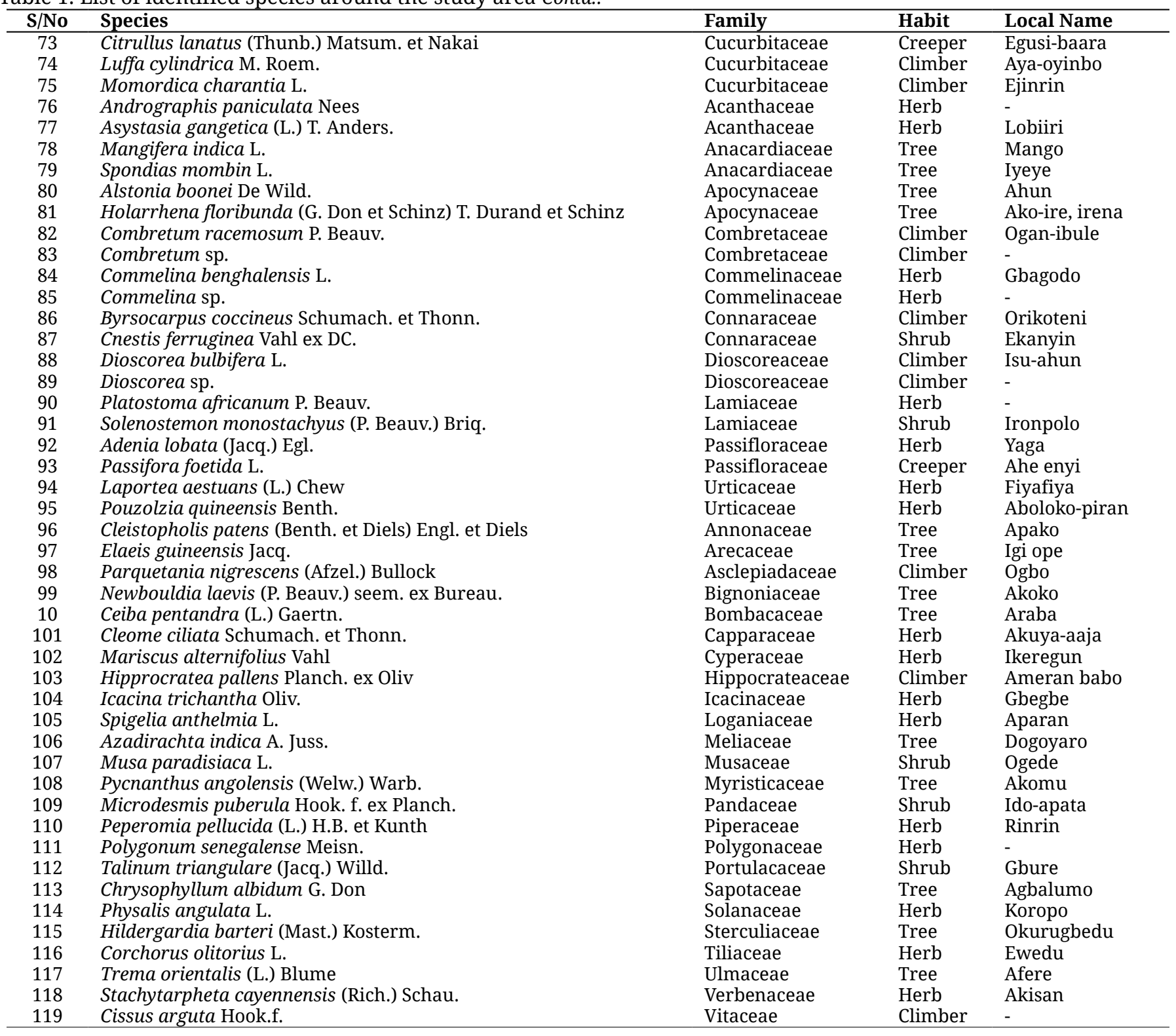

Reservoir has a surface area of 6 ha. According to Ugwumba (1990), the Reservoir is $8.3 \mathrm{~m}$ high, $110 \mathrm{~m}$ long with a crest of $12.2 \mathrm{~m}$ high. It has a maximum depth of $5.5 \mathrm{~m}$ and a maximum length of $700 \mathrm{~m}$. It can hold about 230 million litres of water (Omotosho, 1981). The mean daily air temperature is $24.6^{\circ} \mathrm{C}$. The reservoir is noticeable by two seasons: the wet and dry seasons. Rainy season occurs between April and October while the dry season is between November and March. The water level in the Reservoir is regulated at a spill-way through which excess water flows out so the level remains almost constant throughout the rainy season. However, during the dry season, the water level Reduces.

\section{Species enumeration}

The study was initiated in June, 2013 and completed in October, 2014. Field collection of plant species occurring at 50 meters distance on both sides of the dam was documented. The species were identified using the taxonomic keys provided in Hutchinson et al. (1954-1972), Lowe \& Stanfield (1974), Lowe (1989), Keay (1989) and comparison with previous collections deposited at Forest Herbarium, Ibadan (FHI) (Holmgren et al. 1990). Scientific names were checked and verified from the International Plant Name Index (IPNI) website (http://www.ipni.org). The species were thereafter carefully documented, along with their families, habits and local name(s) with which they are known within the study area.

\section{Results and Discussion}

A total of 119 angiosperm species belonging to 47 families were recorded from the enumeration. These constitute trees, shrubs, herbs and climbers. The most prominent of all the families is Euphorbiaceae, with 15 


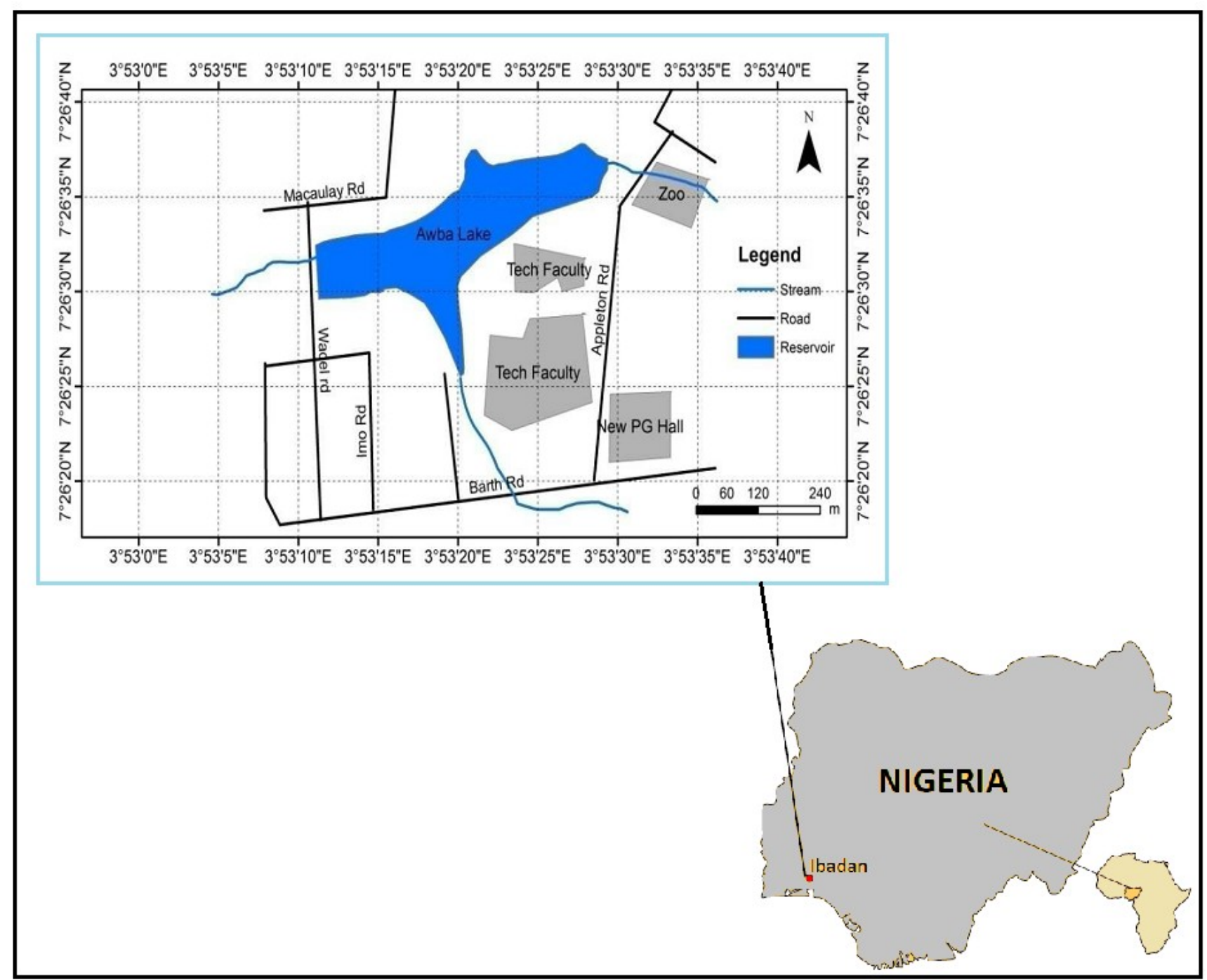

Fig 1. Map of the study area

species, thus constituting $12.6 \%$ of the total enumeration (Table 2). This is closely followed by Asteraceae (8 species; 6.7\%), Moraceae and Papilionaceae with 7 species each (5.9\%). However, a total of 4 families were represented with 5 species each, 3 families had 4 species each, 2 families had 3 species each, 10 families had 2 species each while the remaining 24 families were represented with one species each. The occurrence of these families with single species is a reflection of their role in ecosystem maintenance. Observations also showed that the Legumes generally contributed the largest number of species (Papilionaceae - 7; Caesalpiniaceae - 5; and Mimosaceae - 4). Of these 16 legumes, 8 (50\%) were trees while the remaining 8 comprises shrubs (3), herb (1) climber and creepers (2 each) as shown in Table 1. The presence of these taxa is noteworthy, and as nitrogen fixers, may be said to be responsible for the high fertility nature of the soil around the study area, which has continued to be reliable in the cultivation of several food crops especially vegetables and tubers.
Further results based on the life forms of these plant species also revealed that the study area is dominated by herbs, trees and a number of shrubs. The herbs constitute 44 species (37\%) of the entire enumeration while the trees contribute 35 species $(29 \%)$ and the shrubs, 20 species (17\%). Nonetheless, climbers and creepers were also recorded, with 14 species (12\%) and 6 species (5\%) respectively (Fig 2). It is also interesting to note that of all the 47 plant families identified, the herbs are dominant, and are represented in 22 of these angiosperm families, followed by the trees in 18 families and the shrubs in 11 families. The climbers and creepers are also represented in 10 and 5 families respectively as shown in Fig 3.

The avalanche of species, especially herbs, as recorded in this work is an indication that the study area is home to many plant species that could be screened for medicinal properties, thus reflecting the biodiversity richness of the study area and the University community at large. These plants have overtime been collected by the local people and used in the traditional treatment or management of ailments 


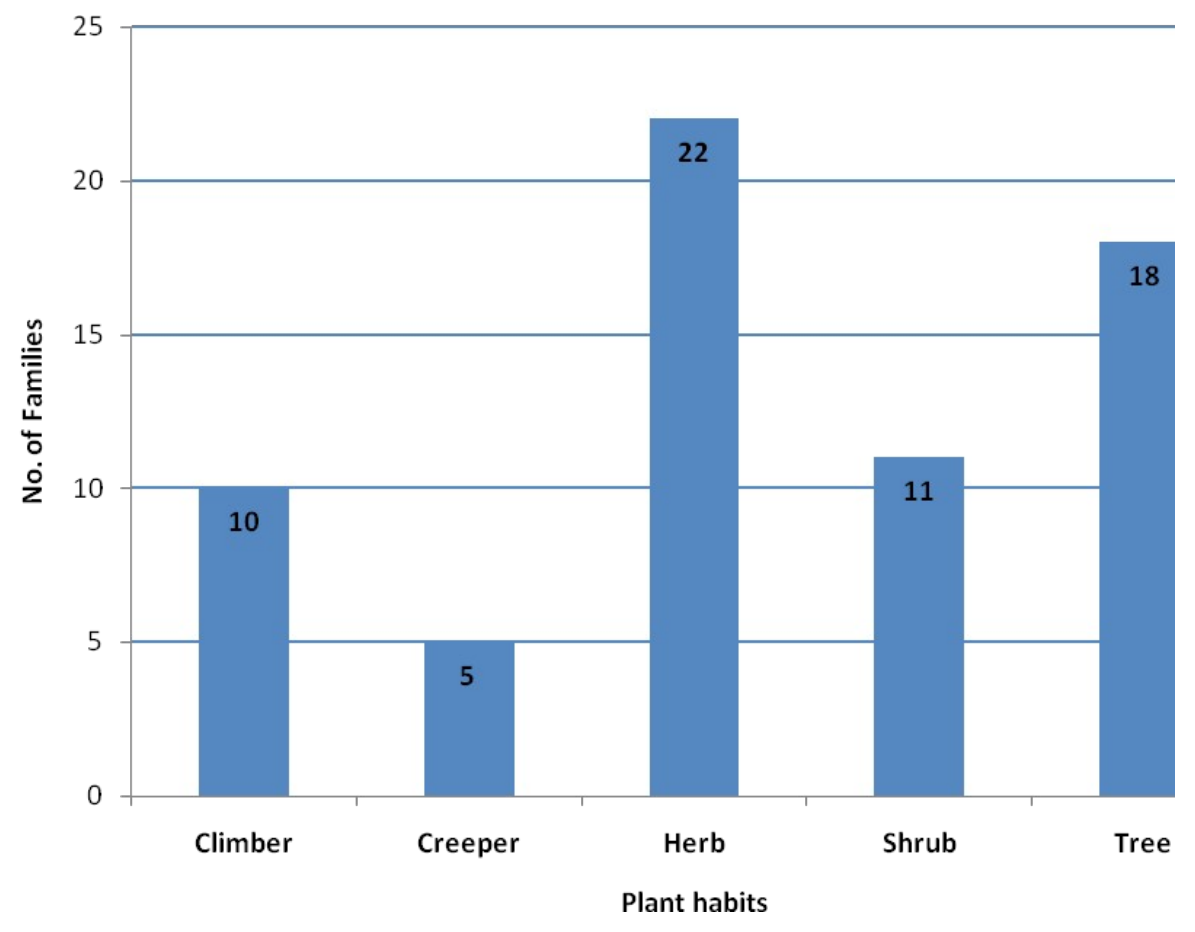

Fig 3. Number of families represented by each plant habit

and have also been reported by some authors of medicinal plants studies such as Gills (1992), Odugbemi (2008) and Soladoye et al. (2012) to mention but a few, while a number of them are also consumed as food in one way or the other. Some of these include: Blighia sapida, Carica papaya, Mangifera indica, Spondias mombin, Talinum triangulare, Vernonia amygdalina etc. Some of the plants identified in this work have also been earlier reported by Ayodele et al. (2013) to be occurring within the zoological garden of the University, where they occur ex-situ. This therefore justifies the importance of plant species in the maintenance of ecosystem and as a source of livelihood for man.

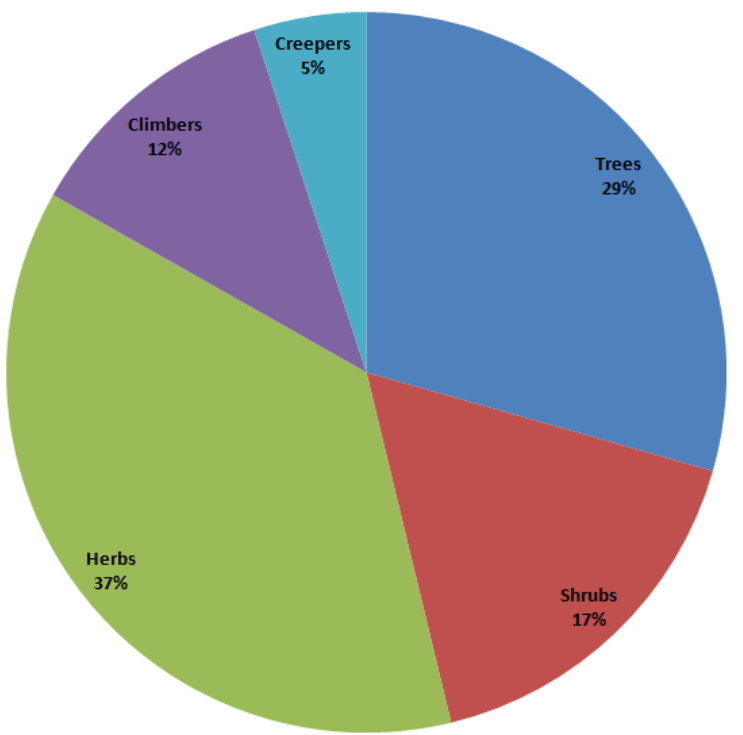

Fig 2. Number of species represented by each plant habit
Aside the numerous flora species reported in this work, the study area also supports the existence of some birds species such as Reed Cormorant (Phalacrocorax africanus), White-Faced Whistling Duck (Dendrocygna viduata), Black-Crowned Night Heron (Nycticorax nyticorax), Common Bulbul (Pycnonotus barbatus), Woodland Kingfisher (Halcyon senegalensis), Black Kite (Milvus migrans), Pied Crow (Corvus albus), Cattle Egret (Bubulcus ibis), Intermediate Egret (Mesophoyx intermedia), Grey Hornbill (Tockus nasutus), WesternGrey Plantain-Eater (Crinifer piscator), Broad-Billed Roller (Eurystomus glaucurus), Fork-Tailed Drongo (Dicrurus adsimilis),etc. These were observed and documented during the course of this work, and identified by the second author. Tyokumbur \& Okorie (2013) in their work also reported the presence of phytoplankton such as Microcystis flos-aquae, Microcystis aeruginosa, Oscillatoria limnetica, Oscillatoria formosa, Pediastrum simplex, Pediastrum duplex, Closterium, peridinium, Euglena, Anabaenopsis, some zooplanktons: Paramecium, Brachionus, Anuraeopsis, Diaphanosoma, Macrocyclops etc in the study area. All these in collaboration, ensures that the study area remains a functional ecological system. However, our rich biodiversity is fast disappearing owing to several human activities as earlier mentioned. The fact that some habitats have been disturbed, either in whole or in part, does not mean that we cannot reinstate them or minimize the adverse effects posed from the current developmental activities. This point was stressed by the Association of Conservation Biology workshop. They noted that it is important to understand that protecting biological diversity, as a practical matter, is independent of the pursuit of the Holy Grail of "pristine". Just because a system is not pristine does not 
mean that it has no value for conservation. The task of conservation is not to preserve some ideal pristine nature; rather, its task is to protect diversity as noted by Arne (1992). Edwin-Wosu and Edu (2013) also pointed out clearly that, for conserving biodiversity, it is fundamental to arrest the loss of natural plant resources by adopting proper conservation strategies and protection of natural regeneration of plant species.

Table 2. Percentage occurrence of species within families

\begin{tabular}{|c|c|c|}
\hline S/No & Family & Species (\%) \\
\hline 1. & Acanthaceae & 1.7 \\
\hline 2. & Amaranthaceae & 4.2 \\
\hline 3. & Anacardiaceae & 1.7 \\
\hline 4. & Annonaceae & 0.8 \\
\hline 5. & Apocynaceae & 1.7 \\
\hline 6. & Arecaceae & 0.8 \\
\hline 7. & Asclepiadaceae & 0.8 \\
\hline 8. & Asteraceae & 6.7 \\
\hline 9. & Bignoniaceae & 0.8 \\
\hline 10. & Bombacaceae & 0.8 \\
\hline 11. & Caesalpiniaceae & 4.2 \\
\hline 12. & Capparaceae & 0.8 \\
\hline 13. & Combretaceae & 1.7 \\
\hline 14. & Commelinaceae & 1.7 \\
\hline 15. & Connaraceae & 1.7 \\
\hline 16. & Convolvulaceae & 2.5 \\
\hline 17. & Cucurbitaceae & 2.5 \\
\hline 18. & Cyperaceae & 0.8 \\
\hline 19. & Dioscoreaceae & 1.7 \\
\hline 20. & Euphorbiaceae & 12.6 \\
\hline 21. & Hippocrateaceae & 0.8 \\
\hline 22. & Icacinaceae & 0.8 \\
\hline 23. & Lamiaceae & 1.7 \\
\hline 24. & Loganiaceae & 0.8 \\
\hline 25. & Malvaceae & 4.2 \\
\hline 26. & Meliaceae & 0.8 \\
\hline 27. & Mimosaceae & 3.4 \\
\hline 28. & Moraceae & 5.9 \\
\hline 29. & Musaceae & 0.8 \\
\hline 30. & Myristicaceae & 0.8 \\
\hline 31. & Pandaceae & 0.8 \\
\hline 32. & Papilionaceae & 5.9 \\
\hline 33. & Passifloraceae & 1.7 \\
\hline 34. & Piperaceae & 0.8 \\
\hline 35. & Poaceae & 3.4 \\
\hline 36. & Polygonaceae & 0.8 \\
\hline 37. & Portulacaceae & 0.8 \\
\hline 38. & Rubiaceae & 4.2 \\
\hline 39. & Sapindaceae & 3.4 \\
\hline 40. & Sapotaceae & 0.8 \\
\hline 41. & Solanaceae & 0.8 \\
\hline 42. & Sterculiaceae & 0.8 \\
\hline 43. & Tiliaceae & 0.8 \\
\hline 44. & Ulmaceae & 0.8 \\
\hline 45. & Urticaceae & 1.7 \\
\hline 46. & Verbenaceae & 0.8 \\
\hline 47. & Vitaceae & 0.8 \\
\hline
\end{tabular}

\section{Conclusion}

This research reveals that the surrounding ecosystem of Awba dam and Nigeria's ecosystems in general, are important sources of food, raw material, medicine and items of trade for mankind. They hold a great potential to transform the nation's agricultural system and contribute to health care improvement. But on the contrary, our species are gradually disappearing. Findings from this work reiterate the fact that, practical conservation of the entire biodiversity especially the flora species existing within and outside the study area is very crucial if species extinction is to be averted, and ecosystem balancing is to be maintained. It may be proper to suggest a close monitoring of the study area to avoid indiscriminate habitat destruction by the inhabitants, visitors to the dam and the entire university community. Consequently, the University management has a great role to play if these goals are to be achieved.

\section{Competing interests}

The authors declare that they have no competing interests.

\section{Authors' contributions}

ECC and TAA initiated the research, and participated in its design and coordination. ECC identified the plant species while the two authors drafted the manuscript. ECC performed the statistical analysis. All authors read and approved the final manuscript.

\section{References}

Adesina, S. K., Z. O. Gbile., O. A. Odukoya., D. D. Akinwusi., H. C. Illoh, and A. A. Jayeola. 1995. Survey of indigenous useful plants of West Africa with special emphasis on medicinal plants and issues associated with management. The United Nations Programme on Natural Resources in Africa; 2nd edition, pp. 84-85.

Akin-Oriola G. A. 2003. On the phytoplankton of Awba reservoir, Ibadan, Nigeria. Revista de Biología Tropical, 51(1): 99-106. http://rbt.biologia.ucr.ac.cr/attachments/volumes/vol51-1/08Akin-PHYTOPLANKTON.pdf

Anago, I. J., I. K. Esenowo, and A. A. A. Ugwumba. 2013.The Physico-chemistry and Plankton Diversity of Awba Reservoir University of Ibadan, Ibadan Nigeria. Research Journal of Environmental and Earth Sciences, 5(11): 638-644. http://maxwellsci.com/print/rjees/v5-638-644.pdf

Ariwaodo, J. O., K. A. Adeniji, and O. D. Akinyemi. 2012. The vascular flora on Asamagbe stream bank, Forestry Research Institute of Nigeria (FRIN) premises, Ibadan, Nigeria. Annals of Biological Research, 3 (4) 1757-1763. http://scholarsresearchlibrary.com/ABR-vol3-iss4/ABR-2012-34-1757-1763.pdf

Arne, N. 1992.'The shallow and the deep, long-range ecology movement: a summary', Inquiry I6, 1973, succinctly explained by Andrew Dobson, Green political thought. London: Routledge, p. 47.

Ayodele, A. A., E. C. Chukwuma, O. A. Adesina., M. O Oyedokun, and T. A. Afolarin. 2013. The Role of Ecotourism in Biodiversity Conservation: A Case Study of the University of Ibadan Botanical and Zoological Gardens. In Proceedings of the $36^{\text {th }}$ Annual Conference of the Forestry Association of Nigeria held at the University of Uyo, Uyo, Akwa-Ibom State, Nigeria, between $4^{\text {th }}-9^{\text {th }}$, November, 2013, pp24-34.

Edwin-Wosu, N. L., and E. A. B. Edu. 2013. Eco-taxonomic assessment of plant species regeneration status in a post 
remediated crude oil impacted site in parts of Ibibio-I-Oil field in Ikot-Ada Udo, Ikot-Abasi local government area of Akwa Ibom State, Nigeria. Asian Journal of Plant Science and Research, 2013, 3(3):14-23. http://pelagiaresearchlibrary.com/asian-journal-of-plantscience/vol3-iss3/AJPSR-2013-3-3-14-23.pdf

Gbile, Z. O., B. A. Ola-Adams, and M. O. Soladoye. 1978. "Endangered Species of the Nigerian flora". Nigerian Journal of Forestry, 8 (1): 14-20.

Gbile, Z. O., B. A. Ola-Adams, and M. O. Soladoye. 1981. List of Rare Species of the Nigerian Flora. Research Paper (Forest series) No 47. (FRIN).

Gills, L. S. 1992. Ethnomedical uses of plants in Nigeria. University of Benin press, Nigeria. P. 276.

Holmgren, P. K., W. Keuken, and E. K. Schofield. 1990. Index Herbariorum Part I. The Habaria of the World. 8th ed. Reg. Veg., 120 - New York.

Hutchinson, J., J. M. Dalziel., R. W. J. Keay., F. N. Hepper, and A. H. G. Alston. 1954-1972. Flora of West Tropical Africa, the British West African Territories, Liberia, the French and Portuguese Territories South of Latitude 18 Degrees North to Lake Chad, and Fernando Po. Secound edition. Crown Agents for Oversea Governments, and Administrations, London.

Keay, R. W. J. 1989. Trees of Nigeria. Oxford University Press, New York, 476pp.

Lowe, J. 1989. The Flora of Nigerian Grasses. Ed. 2. Ibadan University Press.

Lowe, J., and D.P. Stanfield. 1974. The Flora of Nigerian Sedges. Ibadan University Press, 144pp.

Odugbemi, T. 2008. A Textbook of Medicinal Plants from Nigeria. Unilag Press, 628pp.

Oguntala, A. B., M. O. Soladoye., O. A. Ugbogu, and T. R. Fasola. 1996. A Review of Endangered Species of Cross River State and Environs: In Obot E. and Baker J. (Eds). Essential Partnership - The Forest and the People. Proceeding of a Workshop on the Rain Forest of South Eastern Nigeria and South Western Cameroon held at Obudu Cattle Ranch and Resort 20 -24th October, 1996 Pp. 120 - 125.

Okeniyi, A. G., S. B. Raheem., G. F. Oladiran, and O. A. Agbede. 2013. Capacity and Quality Assessment of Awba River Basin. Civil and Environmental Research, 3(2) 9-20. http://.iiste.org/Journals/index.php/CER/article/download/422 $\underline{8 / 4297}$

Okoli, R. I., O. Aigbe., J. O. Ohaju-Obodo, and J. K. Mensah. 2007. Medicinal Herbs Used for Managing Some Common Ailments among Esan People of Edo State, Nigeria. Pakistan Journal of Nutrition, $\quad 6 \quad$ (5): $\quad 490-496$. http://dx.doi.org/10.3923/pjn.2007.490.496

Omotosho, J. S. 1981. Comparative studies of the reproductive biology of the two Cichlids: Tilapia zilli and Sarotherodon niloticus from a small lake in Ibadan Nig. M.Sc. Thesis, University of Ibadan, Ibadan.

Schmidt, K. 1996. Botanical Survey in the Oban division, Cross River National Park. Technical report. Oban Hills Programme, Calabar, Nigeria.

Soladoye, M. O., and O. Oni. 1996. Angiosperm Biodiversity of an Endangered Ecosystem. Nigeria Journal of Forestry, 26(2): 46 $-56$.

Soladoye, M. O., B. A. Asafa., M. A. Sonibare., G. A. Ibhanesebhor, and E. C. Chukwuma. 2011. Angiosperm Flora of Kamuku National Park: A Northern Guinea Savanna Protected Area in Nigeria. European Journal of Scientific Research, 58 (3): 326340.

Soladoye, M. O., E. C. Chukwuma, and F. P. Owa. 2012. An 'Avalanche' of Plant Species for the Traditional cure of Diabetes mellitus in South-Western Nigeria. Journal of Natural Products and Plant Resources, 2 (1): 60-72. http://scholarsresearchlibrary.com/INPPR-vol2-iss1/INPPR2012-2-1-60-72.pdf

Soladoye, M. O., M. A. Sonibare., A. O. Nadi, and D. A. Alabi. 2005. Indigenous Angiosperm Biodiversity of Olabisi Onabanjo
University Permanent Site. African Journal of Biotechnology, 4(5):

554-562.

http://www.academicjournals.org/article/article1380034645 S oladoye $\% 20 \mathrm{et} \% 20 \mathrm{al} . \mathrm{pdf}$

Tyokumbur, E. T., and T. Okorie. 2013. Studies on the distribution and abundance of plankton in Awba stream and reservoir, University of Ibadan. Open Journal of Ecology 3: 273-278. doi: http://dx.doi.org/10.4236/oje.2013.34031

Ugwumba, A. A. A. 1990. Food and feeding ecology of Oreochromis nitoticus, Sarotherodon melanotheron and Heterotis niloticus-AWBA reservior. Ph.D. Thesis, University of Ibadan, Ibadan, pp: 315.

Valdecasas A.G., and Camacho, A. I. 2003. Conservation to the rescue of taxonomy. Biodiversity and Conservation, 12: 11131117. http://dx.doi.org/10.1023/A:1023082606162

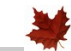

